\title{
Achieving Sustainable Energy Security in Indonesia Through Substitution of Liquefied Petroleum Gas with Dimethyl Ether as Household Fuel
}

\author{
Vincent Felixius ${ }^{1, *}$, Natasya Angelina ${ }^{1}$, Timotius Weslie ${ }^{1}$ \\ ${ }^{1}$ Department of Chemical Engineering, Faculty of Industrial Technology, Institut Teknologi \\ Bandung, Jalan Ganesha No. 10, Bandung 40132, Indonesia
}

Received 25 January 2021; Accepted 15 June 2021

Available online 31 August 2021

\begin{abstract}
Indonesia has been facing an energy security issue regarding Liquefied Petroleum Gas (LPG) consumption. The rapid increase of LPG consumption and huge import have driven the Indonesian government to develop the alternative for LPG in the household sector. Dimethyl ether (DME) is the well-fit candidate to substitute LPG because of its properties similarities. However, discrepancies in the properties, such as combustion enthalpy and corrosivity, lead to adjustments in the application. Coal is a potential raw material to produce DME, especially in Indonesia, known as the fourth-largest coal producer globally. However, the gasification of coal into DME brings a problem in its sustainability. To compensate for the emission, co-processing of DME with biomass, especially from agricultural residue, has been discovered. Recently, carbon dioxide $\left(\mathrm{CO}_{2}\right)$ captured from the gasification process has also been developed as the raw material to produce DME. The utilization of $\mathrm{CO}_{2}$ recycling into DME consists of two approaches, methanol synthesis and dehydration reactions (indirect synthesis) and direct hydrogenation of $\mathrm{CO}_{2}$ to DME (direct synthesis). The reactions are supported by the catalytic activity that strongly depends on the metal dispersion, use of dopants and the support choice. Direct synthesis can increase the efficiency of catalysts used for both methanol synthesis and dehydration. This paper intended to summarize the recent advancements in sustainable DME processing. Moreover, an analysis of DME's impact and feasibility in Indonesia was conducted based on the resources, processes, environmental and economic aspects.
\end{abstract}

Keywords: coal gasification, DME, energy security, LPG, sustainable

\section{Introduction}

Liquefied Petroleum Gas (LPG) is a by-product of the refinery process that mainly consists of propane and butane (Huth \& Heilos, 2013). According to Indonesia's Handbook of Energy \& Economic Statistics of Indonesia (HEESI), in 2018, Indonesia's LPG consumption reached 63.7 million barrels of oil equivalent (MBOE), with a 5.2\% increase from 2017, of which the household sector contributed to $96 \%$ of the consumption. Despite its high consumption, according to Indonesia's Ministry of Energy and Mineral Resources, in 2015 alone, 60\% of LPG in Indonesia came from imports. Moreover, Indonesia's oil and gas production has been decreasing with a reserve to production ratio (RPR) at around $55 \%$, which means for every 1 barrel of oil produced, the industry could only find 0.55 barrel new oil source. This, in fact, has put Indonesia in an energy security problem. Therefore, a race for a new alternative to LPG has been going on for decades.

A well fit candidate to substitute LPG usage is dimethyl ether (DME) due to their similarity. Both LPG and DME are non-toxic properties, produce colored fire and the same vapor pressure range (Parbowo et al., 2019). However, several property discrepancies, such as heat enthalpy and corrosivity can impact the feasibility of DME usage. DME is mainly used as an 'ozone-friendly' propellant in spray cans. Usually, DME is derived from natural gas (NG) or methanol (Nieuwenhuis \& Wells, 2003).

*Corresponding author

E-mail address: vincentfelixius@gmail.com 
DME can also be synthesized through the gasification of coal. Indonesia has a tremendous amount of coal with a national reserve of 26.2 billion tons, the fourth largest coal producer globally. Coal gasification into DME is not a new thing. Korea, which is known for its NG-based DME producer, has been researching to substitute NG with coal to cut the dependence on imported crude oil (Kim et al., 2012). The utilization of DME can decrease the import of LPG in Indonesia (Boedoyo, 2016). To reduce greenhouse gas (GHG) emissions of the DME production, biomass can be integrated with coal through co-gasification process (Howaniec \& Smoliński, 2014). Biomass is a potential energy resource for its abundance in Indonesia, especially from agricultural waste, but most of the resources were underutilized. Therefore, DME can also increase the domestic usage of coal and support Indonesia's development of energy.

Using coal as a feedstock still posed a threat to the environment. Coal gasification to DME even contributed to GHG emission of up to $5.5 \mathrm{~kg} \mathrm{CO}_{2}$ eq per $\mathrm{kg}$ DME (Lecksiwilai et al., 2016). To fulfill national demand, around 6.37 Mt of DME is needed, which emits $35.04 \mathrm{Mt}$ of $\mathrm{CO}_{2}$ eq per year. Therefore, to achieve a lower carbon footprint, advancements have to be made in producing the DME. Some advancements include using biomass, removing $\mathrm{CO}_{2}$ and more recently utilizing $\mathrm{CO}_{2}$ as the material to produce DME. A more detailed explanation of the processes will be presented in this work.

Given its potential, there are some essential points regarding DME sustainability. First, it does not come from renewable resources. Even though the Ministry of Energy and Mineral Resources Republic of Indonesia (ESDM) projected that coal reserves' age is still 56 years, other sustainable resources have to be discovered for national energy security. Second, DME processing and application have to be environmentally safe, both in DME production chain and emissions. Third, DME implementation has to be economically feasible at the industrial level.

Therefore, this work aims to analyze DME's potential in Indonesia based on the resources, processes, environmental and economic aspects and explain the long-term sustainability of DME production. In this paper, some scenarios in which DME utilization can lessen LPG consumption was analyzed to better understand its feasibility and impact.

\section{DME potency to substitute LPG}

\subsection{LPG in Indonesia}

The discussion of household fuel in Indonesia will always remind the national program, known as the Zero Kero program, to convert domestic kerosene users to liquefied petroleum gas (LPG) for cooking in 2007. Kerosene was the primary cooking fuel for 37\% of households in that era (MEMR, 2016a). However, the amount of government subsidy on household kerosene became burdensome. In 2008, the total subsidy escalated for more than twice in 2005, reaching up to USD 5.24 billion due to the weakening in domestic supply and increase in oil prices (Budya \& Yasir Arofat, 2011). Therefore, LPG was chosen by the government as the substitute for kerosene because LPG's higher calorific value would make it cheaper to subsidize (MEMR, 2007). The other reason was the easier supply chain because LPG with storage tanks and filling plants was easy to distribute even to remote populations.

The Zero Kero program gained enormous success to make Indonesian households shift to LPG as kerosene consumption shrank 92\% from 10 million kiloliters (kl) in 2006 to 0.8 million $\mathrm{kl}$ in 2015 . On the other side, LPG consumption rose convincingly from 1.1 million tons (Mt) to $6.3 \mathrm{Mt}$ in 2015, so that Indonesia became at the same level as mature LPG markets like Brazil in LPG consumption per capita (Thoday et al., 2018). This program made the government save until IDR 216,4 trillion compared to subsidizing kerosene (MEMR, 2016b). However, the booming demand for LPG has become another problem. The Zero Kero program penetrated the LPG consumption increase annually even though the program has ended. In 2018, 63.7 million Barrel Oil Equivalent (MBOE) of LPG were consumed, and $96 \%$ by the household sector (Sekretariat Jendral Dewan Energi Nasional, 2019). Indonesia has been a net-importer oil country since 2004. Therefore, the government had to import LPG to fulfill demand. The Zero Kero program drove the LPG import to reach 64\% of the total demand in 2015 (MEMR, 
2016a). It increases annually until 5.5 million tons of LPG were imported in 2018 (Sekretariat Jendral Dewan Energi Nasional, 2019). Thus, to control the increasing of LPG import, Indonesia government is developing an alternative energy, which is DME produced from coal gasification. To solve the weak local LPG production, Indonesia government is developing gasification of coal, which is abundant in Indonesia, to produce DME.

\subsection{DME as the LPG Substitution}

DME with the chemical formula $\mathrm{CH}_{3} \mathrm{OCH}_{3}$ is the simplest ether with the lowest carbon to hydrogen ratio. Under standard atmospheric conditions (1 atm, $298 \mathrm{~K}$ ), DME is in the gaseous state. It is a colorless, non-toxic and environmentally safe gas. DME is condensable by pressurization above $5 \mathrm{~atm}$. Given its fuel characteristic, DME produces visible blue flame while burning, comparable with LPG. DME is the potential candidate to substitute LPG because of its physical properties similarity, and it is possibly produced from many sources, such as coal, natural gas and biomass (Larson \& Yang, 2004). In some properties, DME is approximately the average of propane and n-butane, two primary LPG components. However, there are still discrepancies in the physical properties caused by the different chemical structures between DME and LPG. The most contrasting differences are combustion enthalpy and corrosivity. DME has a lower combustion enthalpy compared to LPG as it is an oxygenated fuel. Therefore, to substitute LPG, a larger DME volume should be injected into the larger tank (Constantine, 2008). Stronger corrosivity on rubber material also brings adjustment on DME application. Rubber material in the stove, like seals, gasket and pressure regulator, will dissolve and harm the safety aspect if no modifications are done (N. Wu et al., 2008). Hence, it is compulsory to consider those different properties in the DME application (Ohno, 2007). Table 1 contains physical properties information of DME, propane and n-butane.

Table 1. Physical properties data of DME, propane and n-butane (Arya et al., 2016).

\begin{tabular}{lllll}
\hline Properties & Unit & DME & Propane & n-Butane \\
\hline Molecular weight & $\mathrm{g} / \mathrm{mol}^{3}$ & 46.07 & 44.10 & 58.12 \\
Liquid density & $\mathrm{g} / \mathrm{cm}^{3}$ & 0.67 & 0.49 & 0.599 \\
Gas density & $\mathrm{g} / \mathrm{cm}^{3}$ & 2.057 & 1.969 & 2.595 \\
Melting point & ${ }^{\circ} \mathrm{C}$ & -141.5 & -189.69 & -138.32 \\
Boiling point & ${ }^{\circ} \mathrm{C}$ & -24.8 & -42 & -11.7 \\
Flash point & ${ }^{\circ} \mathrm{C}$ & -41.11 & -104 & -72 \\
Adiabatic flame temperature & ${ }^{\circ} \mathrm{C}$ & 1954 & 1977 & 1982 \\
Vapour pressure & $\mathrm{MPa} @ 293 \mathrm{~K}$ & 0.530 & 0.9119 & 0.21 \\
Liquid viscosity & $\mathrm{cP}$ & 0.15 & 0.099 & 2.074 \\
Gas viscosity & $10^{-6} \mathrm{P}$ & 9.160 & 7.99 & 7.36 \\
Cetane number & - & $55-60$ & 5 & - \\
High Heating Value (HHV) & $\mathrm{MJ} / \mathrm{kg}$ & 31.7 & 50.34 & 49.49 \\
Low Heating Value (LHV) & $\mathrm{MJ} / \mathrm{kg}$ & 28.8 & 46.4 & 48 \\
Wobbe index & $\mathrm{MJ} / \mathrm{m}^{3}$ & 52 & 81 & 91 \\
Combustion enthalpy & $\mathrm{kJ} / \mathrm{mol}$ & -1460.4 & -2220 & -2877.5 \\
Copper Corrosivity & $\mathrm{ASTM} \mathrm{D}-1838$ & $1 \mathrm{a}$ & $1 \mathrm{~b}$ & $1 \mathrm{~b}$ \\
\hline
\end{tabular}

Some discrepancies in properties and the current stove design have led DME-LPG blend fuel to be more feasible. A study by (Matsumoto et al., 2004) found that pure DME was applicable in the methane stove with minor modification. It is supported by the DME's Wobbe Index that is closer to methane than propane and butane. The improbability of using pure DME to substitute LPG entirely has triggered the study by researchers to find the proper portion of DME and investigate its heating performance. Marchionna et al. (2008) used five conventional LPG cooking stoves with three different burners to find that DME's optimum volume concentration in LPG mixtures was 15-20\%.

Makmool and Jugjai (2013) also confirmed the same optimum concentration. They tested DME-LPG blend up to $30 \%$ in the conventional burner (CB) and porous radiant burner (PRB). In general, up to $30 \%$ of DME can be used in the LPG burner, but $20 \%$ of DME is the best portion. Blending DME with 
LPG improved the combustion efficiency as it can significantly reduce the $\mathrm{CO}$ and $\mathrm{NO}_{\mathrm{X}}$ emission. However, the limitation was the decreased thermal efficiency due to increased DME concentration at the fixed fuel supply pressure.

Moreover, at higher than 20\% DME, thermal efficiency significantly decreases because of reduced radiation efficiency. Anggarani et al. (2014) did another investigation that used up to 50\% DME in 6 commercial stoves in Indonesia. The experiment referred to SNI 7368:2007 method investigated the heat consumption, fuel efficiency and flame stability of DME-LPG blend fuel. Heat consumption and fuel efficiency stove decreased as the DME concentration increased. These tendencies were explainable respectively by the DME's calorific value that is nearly half of LPG's, and the design of current stoves was more compatible with pure LPG. All stoves produced good flame stability when fuelled with a DME-LPG blend.

The Research and Development Center for Oil and Gas Technology of Indonesia (LEMIGAS) has developed the DME stove to utilize 100\% DME (ESDM, 2020). The evaluation using SNI 7368:2011 method showed that the DME stove's efficiency was 64.7-68.9 \%, better than the conventional LPG stove with 53.75-59.13\% efficiency. Implementation test of DME stove conducted in Palembang and Jakarta cities on 255 households. From the test, the conclusion was that DME stove usage was feasible and had a comparable performance as LPG stove with a drawback of 1.1-1.2 longer cooking time.

\section{Advancements in DME Production Towards Sustainability}

\subsection{Co-processing of DME from Low-rank Coal and Biomass}

Biomass has been appealing alternative resources to produce DME, especially in Indonesia as an agricultural country. Using biomass as the resource for the gasification of DME could reduce the greenhouse gas (GHG) emissions of the process. Table 2 summarizes GHG emissions from DME utilization from various agricultural residue and coal as a comparison.

Table 2. GHG emissions of DME utilization from various feedstocks (Lecksiwilai et al., 2016).

\begin{tabular}{ll}
\hline Feedstocks & GHG emission $\left(\mathrm{kg} \mathrm{CO}_{2} \mathrm{e}\right.$ per kg DME) \\
\hline Sugarcane tops and leaves & 0.89 \\
Empty fruit bunches & 1.75 \\
Rice straw & 1.24 \\
Cassava rhizome & 2.11 \\
Maize straw & 0.93 \\
Coal & 5.50 \\
\hline
\end{tabular}

It can be seen that the utilization of agricultural residue has a significant impact in lowering GHG emissions of DME than coal up to $4.61 \mathrm{~kg} \mathrm{CO}_{2} \mathrm{e}$ per $\mathrm{kg}$ DME. However, to ensure the carbon neutrality of biomass gasification to DME, more thorough research is needed, including the source of energy required to process and transport biomass. The effect of deforestation as biomass comes from the plantation (Johnson, 2009).

A simplified block flow diagram (BFD) of biomass gasification into DME can be seen in Figure 1. 


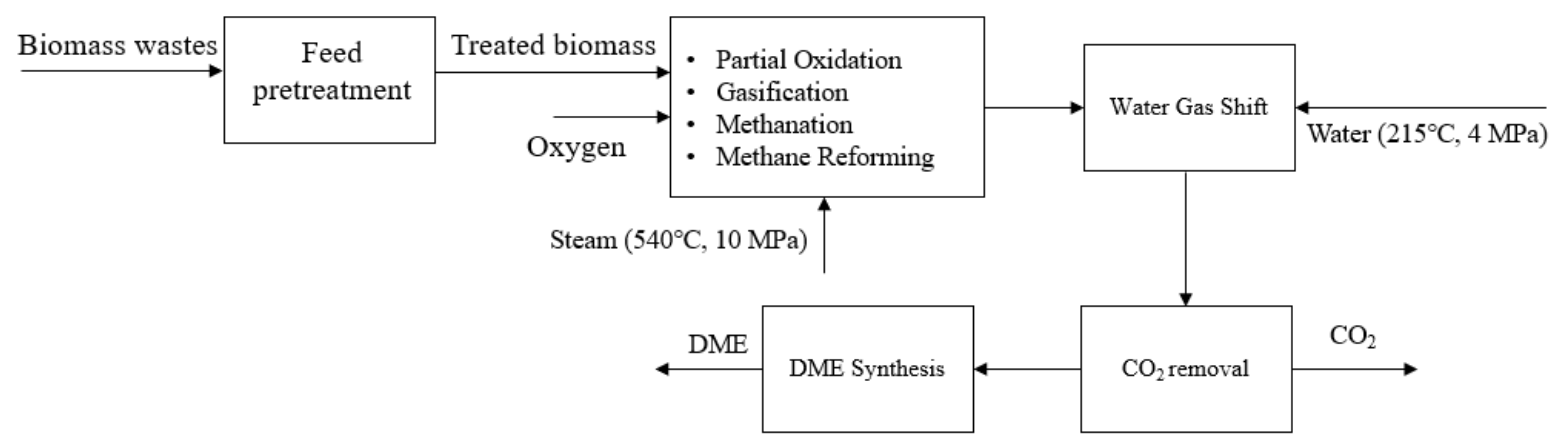

Figure 1. BFD of DME Gasification from biomass (Inayat et al., 2017).

The processing of biomass into DME is not distinct from the gasification process of coal. However, pretreatment steps are needed to screen from unwanted impurities and dry biomass until a specific moisture level to achieve an optimum feedstock condition. The difference between biomass and coal gasification are listed in Table 3 .

Table 3. Difference between coal and biomass gasification.

\begin{tabular}{|c|c|c|c|}
\hline Parameter & Coal Gasification & Biomass Gasification & References \\
\hline Pretreatment & $\begin{array}{l}\text { Drying and size } \\
\text { reduction }\end{array}$ & $\begin{array}{l}\text { Drying, Torrefaction, } \\
\text { and size reduction }\end{array}$ & $\begin{array}{l}\text { (Mamvura \& } \\
\text { Danha, 2020) }\end{array}$ \\
\hline $\begin{array}{l}\text { Optimum Gasification } \\
\text { Temperature }\end{array}$ & $782^{\circ} \mathrm{C}$ & $1668^{\circ} \mathrm{C}$ & (Prins et al., 2007) \\
\hline Hydrogen/Carbon Ratio & Low & High & (Burnham, 2018) \\
\hline Oxygen/Carbon Ratio & High & Low & (Burnham, 2018) \\
\hline
\end{tabular}

As biomass needs to be pretreated through torrefaction, a conventional coal gasification reactor is not suitable for the task (Basu, 2013). Moreover, torrefaction of biomass accounted for a large sum of energy in the gasification process, making it less economically attractive than coal gasification (Howaniec \& Smoliński, 2014).

A more viable approach is to co-process biomass and low-rank coal into DME. In a co-gasification study, Howaniec and Smoliński (2014) reported an increase in gasification efficiency when using several biomass types, such as basket willow (Salix Viminalis) and big bluestem grass (Andropogon Gerardi), at a fuel blend ranging from $40-60 \%$ of the biomass. Moreover, they reported higher hydrogen yield ranging from $7-15 \%$ when using $40 \%$ biomass. A similar result on higher hydrogen yield with co-gasification has also been achieved by Li et al. (2010). In their study, Li et al. (2010) used pine sawdust and rice husk as biomass sources. They reported an increase of hydrogen yield from $17.66 \%$ to $19.30 \%$ when the biomass ratio was increased from $20 \%$ to $33 \%$ (Li et al., 2010).

An increase in hydrogen composition could lead to a higher DME yield as it promotes methanol forming, which is a crucial intermediate-product in DME gasification (Shim et al., 2009). As a result, an increase in hydrogen yield will subsequently increase DME production. The reaction taking up from the production of methanol from the hydrogenation of carbon dioxide, according to the following reaction:

$$
\mathrm{CO}_{2}+3 \mathrm{H}_{2} \leftrightarrow \mathrm{CH}_{3} \mathrm{OH}+\mathrm{H}_{2} \mathrm{O}
$$

Then, DME is formed from alcohol dehydration:

$$
2 \mathrm{CH}_{3} \mathrm{OH} \leftrightarrow \mathrm{CH}_{3} \mathrm{OCH}_{3}+\mathrm{H}_{2} \mathrm{O}
$$

In the reverse water shift reaction, carbon dioxide reacts with hydrogen to be carbon monoxide: 


$$
\mathrm{CO}_{2}+\mathrm{H}_{2} \leftrightarrow \mathrm{CO}+\mathrm{H}_{2} \mathrm{O}
$$

Then, the final reaction leading to the formation of DME as below:

$$
2 \mathrm{CO}_{2}+6 \mathrm{H}_{2} \leftrightarrow \mathrm{CH}_{3} \mathrm{OCH}_{3}+3 \mathrm{H}_{2} \mathrm{O}
$$

\section{2 $\mathrm{CO}_{2}$ Capture in Coal Gasification}

The current trend of energy production is shifting to less $\mathrm{CO}_{2}$ emission. One step in the DME synthesis process is the water-gas shift reaction, which reacted with $\mathrm{CO}$ in syngas with steam to produce $\mathrm{H}_{2}$ and a by-product of $\mathrm{CO}_{2}$. During the next process, $\mathrm{CO}_{2}$ needs to be removed before DME synthesis to avoid a decrease in DME yield (Kabir \& Bhattacharya, 2011). The decrease in DME yield happened due to $\mathrm{CO}_{2}$ competing for hydrogenation and acidic sited of the bi-functional catalyst, thus reducing the methanol dehydration rate (Brown et al., 1991).

Without proper handling, this $\mathrm{CO}_{2}$ could end up in the atmosphere as emissions. Some methods are available in capturing $\mathrm{CO}_{2}$ in this process, such as physical and chemical adsorption. Physical adsoprtion is widely used due to its advantages, with an example of Selexol absorbent method. The Selexol absorbent method was innovated by Union Carbide, which utilizes dimethyl ether of polyethylene glycol (DMPEG) as a physical absorbent (B. Miller, 2015). The advantages of this method are using a small amount of energy to regenerate solvent, utilizing inert gas for solvent stripping and flexibility of utilization with or without refrigeration (Ghasem, 2020). The small amount of energy required to regenerate the solvent is due to no chemical reaction is involved in the process (Fahim et al., 2010). The process flow diagram of this process can be seen in Figure 2.

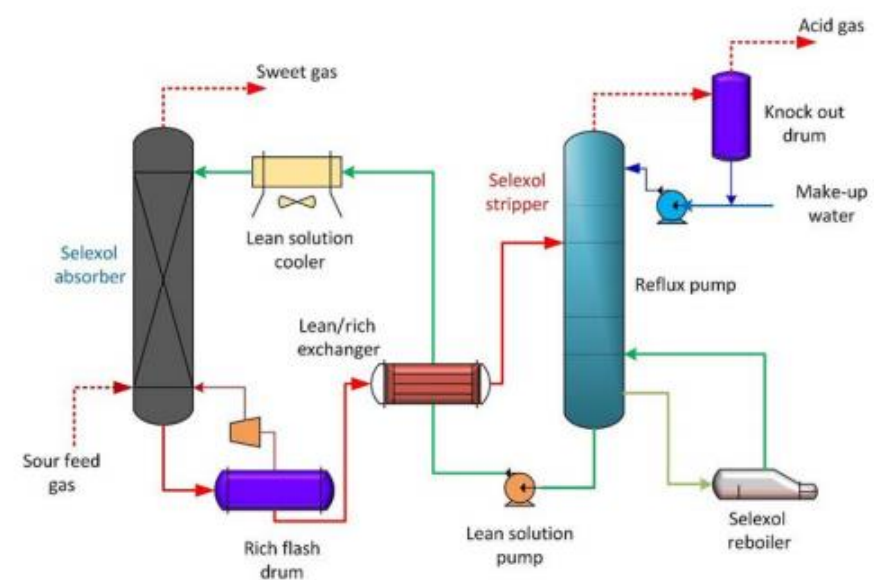

Figure 2. Schematic diagram of a typical Selexol process (B. G. Miller, 2011).

The captured $\mathrm{CO}_{2}$ can then be stored and utilized further. One example of $\mathrm{CO}_{2}$ utilization is mineral carbonation. Mineral carbonation involves reacting $\mathrm{CO}_{2}$ with metal oxides to form carbonates. Furthermore, mineral carbonation is more economically attractive than storage in geological formation as carbonates can be utilized in the construction industry (von der Assen et al., 2013). More promising advancement has been made to utilize this $\mathrm{CO}_{2}$, which is through recycling into DME. A detailed discussion about this technology is presented in the following subsection.

\subsection{Alternatives in the Utilization of $\mathrm{CO}_{2}$ to DME}

Utilization of $\mathrm{CO}_{2}$ recycling into DME consists of two approaches: 1) Methanol synthesis and dehydration reactions (indirect synthesis), and 2) Direct hydrogenation of $\mathrm{CO}_{2}$ to DME (direct synthesis) (Centi et al., 2013). Overall economic merits of the direct synthesis can reduce their capital cost. However, most Chinese companies decided to use indirect synthesis to minimize technology risks 
and diversify methanol marketing options. The direct synthesis has not yet been proven in large scale commercial plants (Fleisch et al., 2012).

Both of the approaches need hydrogen as one of the reactants. Ensuring the process can be a reliable option, hydrogen needs to be produced using renewable energy sources. There are several ways to produced renewable hydrogen: 1) hydrogen production from cyanobacteria (Tamagnini et al., 2002), 2) biomass thermochemical process (Kalinci et al., 2009), 3) photoelectrolysis to split water into hydrogen (Takanabe, 2017), 4) water electrolysis using fuel cells (Centi et al., 2013). Photoelectrolysis using a anion exchange membrane (AEM) is used the more than other alternatives. Enapter, the leader of AEM technology has build the first mass production facility at Germany (Hannovermesse, 2020). Other than that, photoelectrolysis can be done by integrating with the other renewable electricity production that has been increasing over years (Armijo \& Philibert, 2020).

\subsubsection{Indirect Synthesis: Methanol Synthesis and Dehydration reactions}

Production steps of DME shown in Equation (1) and (2) requires the usage of catalysts. The most active for the activation of carbon dioxide is $\mathrm{Cu}$ or copper-based systems (Sugawa et al., 1995). The catalytic activity strongly depends on the metal dispersion, use of dopants and the support choice (Wambach et al., 1999). Table 4 lists the best-performing catalysts and preparation methods for the methanol synthesis.

Table 4. Catalytic properties of $\mathrm{M} / \mathrm{ZrO}_{2}$ catalysts.

\begin{tabular}{llll}
\hline $\begin{array}{l}\text { Catalyst } \\
\mathrm{M} / \mathrm{ZrO}_{2}\end{array}$ & Preparation & $\begin{array}{l}\text { Product Selectivity } \\
\left(\mathrm{CH}_{4}(\%)\right)\end{array}$ & Ref. \\
\hline $\mathrm{Ni}$ & Alloy & 100 & (Haryanto et al., 2005) \\
$\mathrm{Rh}$ & Impregnation & 100 & (Palo et al., 2007) \\
$\mathrm{Ru}$ & Impregnation & 100 & (Vicente et al., 2013) \\
$\mathrm{Rh}-\mathrm{Mo}$ & Impregnation & 100 & (Semelsberger, Ott, et al., 2006) \\
\hline
\end{tabular}

Most studies have used $\mathrm{Cu}$-based support on $\mathrm{ZnO}$ for $\mathrm{CO}_{2}$ hydrogenation. The nature of the carrier oxide can influence the activity of copper. $\mathrm{Zn}$ gives compelling advantages compared to other oxides like $\mathrm{Cr}_{2} \mathrm{O}_{3}, \mathrm{SiO}_{2}$ and $\mathrm{MnO}$. Geometrical spacer in the $\mathrm{Cu}$ nanoparticles is needed and $\mathrm{Cu}$ metal need to be active with $\mathrm{ZnO}$ in the $\mathrm{CuZnO}$ catalyst. It provides a high number of active sites exposed to gaseous reactants (Aguayo et al., 2007). Moreover, the addition of trivalent ions to the catalyst can improve stability, $\mathrm{Cu}$ dispersion and metal surface area. One of the catalyst used for methanol synthesis is $\mathrm{Cu} / \mathrm{ZnO} / \mathrm{Al}_{2} \mathrm{O}_{3}(\mathrm{CZA})$ catalyst. It operates at pressure from $50-100$ bar and temperature of $250{ }^{\circ} \mathrm{C}$ (Jeong et al., 2013). There are some studies of the unique features of various metals added as the promoters of $\mathrm{Cu}-\mathrm{Zn}$ based catalysts such as Al (Samei et al., 2012), Cr (Fujiwara et al., 1994), Si (Batyrev et al., 2005) and carbon (Fan \& Wu, 2016).

Methanol dehydration can be carried out in both vapour and liquid phase with temperature in of 100 $300{ }^{\circ} \mathrm{C}$ and pressure up to $20 \mathrm{bar}$. A high surface area with good thermal and mechanical stability but still affordable can be acquired using $\gamma-\mathrm{Al}_{2} \mathrm{O}_{3}$. It has a high selectivity to DME due to the presence of weak Lewis acid that cannot promote side reactions (Azizi et al., 2014). These acid characteristics need to be reacted at a temperature higher than $250{ }^{\circ} \mathrm{C}$ to achieve the high methanol conversion which aligned with the catalyst ability to achieve high selectivity at temperature up to $400{ }^{\circ} \mathrm{C}$. Moreover, the catalyst activity can enhance their performance with silica, aluminium-phosphates, titanium, boron and other species (Liu et al., 2011). The downsides of using this catalyst is that it absorbs water produced during the reaction causing deactivation. So, $\gamma-\mathrm{Al} 2 \mathrm{O} 3$ is not reliable for the methanol dehydration.

\subsubsection{Direct Synthesis: Direct Hydrogenation $\mathrm{CO}_{2}$ to DME}

Direct synthesis is a single-step process to produce $\mathrm{DME}$ from $\mathrm{CO}_{2}$ using a hybrid catalyst (Frusteri et al., 2017). It can increase the efficiency of catalysts used for both methanol synthesis and dehydration. 
Efficiency can be achieved by minimizing the yield of CO from the Reverse Water Gas Shift (rWGS) side reaction, also hydrocarbons from methanol conversion. It is caused by the water formed from $\mathrm{CO}_{2}$ hydrogenation to DME caused to lower the DME yield from both formation and dehydration of methanol (Azizi et al., 2014). Some alternatives to the catalyst for the direct synthesis shown in Table 5 .

Table 5. The alternative catalyst for $\mathrm{CO}_{2}$ to DME hydrogenation. $\mathrm{X}_{\mathrm{CO} 2}$ : conversion of $\mathrm{CO}_{2}, \mathrm{Y}_{\mathrm{DME}}$ : yielf of DME-product.

\begin{tabular}{|c|c|c|c|c|}
\hline Catalyst & Preparation Method & $\mathrm{X}_{\mathrm{CO} 2}(\%)$ & $\mathrm{Y}_{\mathrm{DME}}(\%)$ & Ref. \\
\hline $\mathrm{Cu} / \mathrm{Zn} / \mathrm{Al}$ HZSM5 & Physical Mixing & 31 & 19 & (Naik et al., 2011) \\
\hline Cu/Zn/Zr/V ZSM5 & Co-Precipitation & 9.1 & 19.1 & (Zhang et al., 2014) \\
\hline $\mathrm{Cu} / \mathrm{Zn} / \mathrm{Al} / \mathrm{La}$ ZSM5 & Physical Mixing & 43.8 & 31.2 & (GAO et al., 2013) \\
\hline $\mathrm{Cu} / \mathrm{Zn} / \mathrm{Al} \mathrm{ZSM} 5+\mathrm{CNTs}$ & Physical Mixing & 46.2 & 21 & (Zha et al., 2013) \\
\hline $\begin{array}{l}\mathrm{Cu} / \mathrm{Zn} / \mathrm{Al} \text { Amorphous silica- } \\
\text { alumina }\end{array}$ & Co-Precipitation & 28.4 & 20.1 & (Zha et al., 2012) \\
\hline
\end{tabular}

Direct synthesis can also be done by gel-oxalate co-precipitation of CuZnZr precursors in a slurry solution of three homemade hybrid systems zeolite, which are MOR, FER and MFI. MOR structure was synthesized with structure-directing agents (SDA) from the molar composition of $0.20 \mathrm{Na}_{2} \mathrm{O}-0.02$ $\mathrm{Al}_{2} \mathrm{O}_{3}-1.0 \mathrm{SiO}_{2}-20 \mathrm{H}_{2} \mathrm{O}$. FER structure was prepared from the following gel, the molar composition of $0.12 \mathrm{NaO}-1.30 \mathrm{C}_{2} \mathrm{DN}-0.07 \mathrm{Al}_{2} \mathrm{O}_{3}-1.0 \mathrm{SiO}_{2}-39.0 \mathrm{H}_{2} \mathrm{O}$. MFI was prepared following the synthesis gel, the molar composition of $0.10 \mathrm{NaO}-0.02 \mathrm{Al}_{2} \mathrm{O}_{3}-0.08 \mathrm{TPABr}-1.0 \mathrm{SiO}_{2}-20 \mathrm{H}_{2} \mathrm{O}$ (Migliori et al., 2014). The activity selectivity pattern of the catalyst in the $\mathrm{CO}_{2}$ to $\mathrm{DME}$ hydrogenation reaction showed the CZZ-FER system's best performance reaching a $\mathrm{CO}_{2}$ conversion of $28 \%$ at $280{ }^{\circ} \mathrm{C}$ with a selectivity of $\mathrm{DME} / \mathrm{MeOH}$ to $70 \%$. At $260{ }^{\circ} \mathrm{C}$ and $5.0 \mathrm{MPa}$, the CuZnZr-FER system reached the highest final space time yield (STY) for about $600 \mathrm{gDME} / \mathrm{kgcat} / \mathrm{h}$ compared to other hybrid systems at around 450 $500 \mathrm{gDME} / \mathrm{kgcat} / \mathrm{h}$ on Figure 3. This was able to be done because of the active sites' progressive blockage due to the formation of water during the catalytic experiments as it was the primary effect of the catalyst stability (Frusteri et al., 2017).

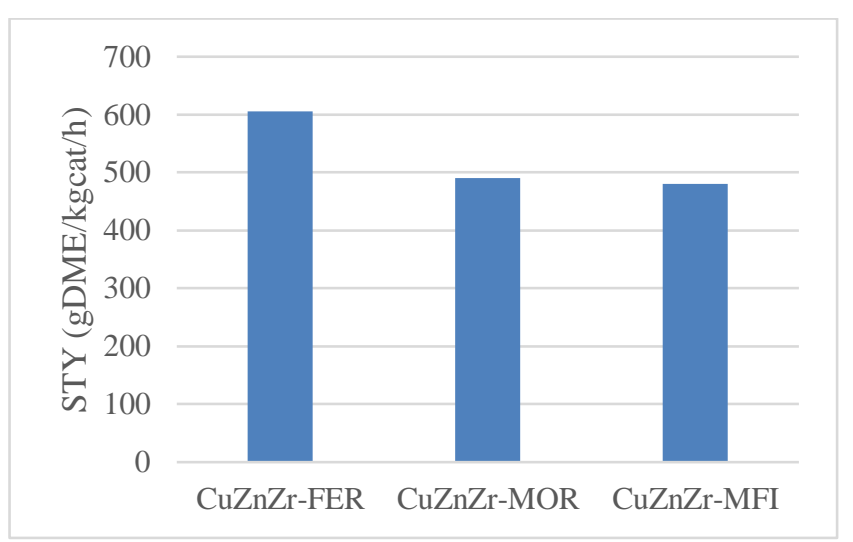

Figure 3. DME productivity in physical mixtures and hybrid catalyst. P: $5.0 \mathrm{MPa}, \mathrm{T}: 260{ }^{\circ} \mathrm{C}$, $\mathrm{CO}_{2} / \mathrm{H}_{2} / \mathrm{N}_{2}: 3 / 9 / 1$. (Frusteri et al., 2017). 


\section{Feasibility and Impacts of DME-LPG Blend Fuel in Indonesia}

\subsection{Feasibility}

Indonesia's coal production is predicted to increase (Figure 4) (DEN, 2018). In 2018, the total production of coal in Indonesia was about $492 \mathrm{Mt}$, only $24.6 \%$ used for domestic demands (Dirjen, 2018). The rest, 75.4\%, were exported as one of the highest Indonesia's economic income (Dirjen, 2018). The National Energy Policy (KEN) stated that energy should support national development. Therefore, General Planning of National Energy (RUEN) was made to realize the new allocation of energy resources in national development. Figure 5 showed the RUEN of coal in Indonesia (Government's Regulation No. 22/2017).

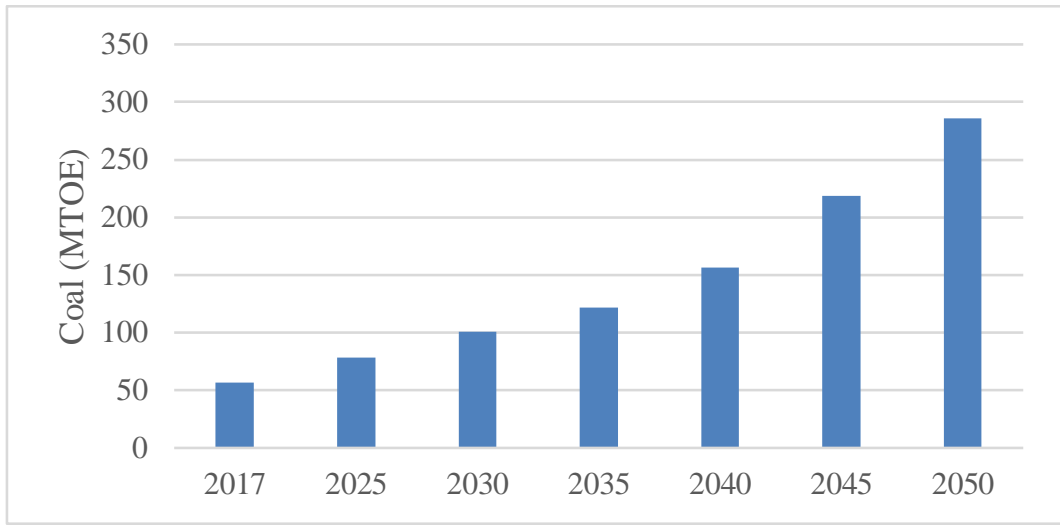

Figure 4. Data Modelling of coal as primary energy resources (DEN, 2018).

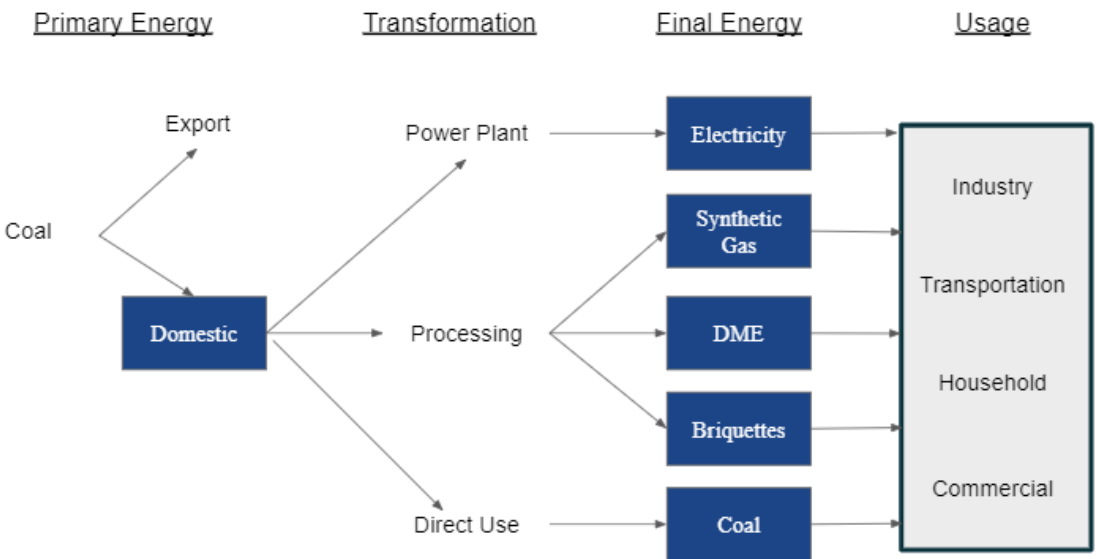

Figure 5. RUEN illustration of the optimization of coal usage (RUEN, 2017).

On the other side, biomass brings more advantages for sustainability. The processing of biomass waste can provide energy, especially to be DME resources. To ensure technical and economical feasibility of biomass utilization in gasification, the ideal mix of biomass can be up to $40 \%$. Above $40 \%$, the energy needed to process biomass would be to high which resulted in lower yield of DME (Howaniec \& Smoliński, 2014). The abundance of biomass has triggered the government to maximize the opportunity to produce renewable energy planned in the national energy mix target. Table 6 summarized the biomass potential in Indonesia. 
Table 6. Biomass Potential in Indonesia (ESDM, 2016).

\begin{tabular}{llr}
\hline No & Potency Source & Total (MW) \\
\hline 1 & Palm Oil & 12,654 \\
2 & Sugar Cane & 1,295 \\
3 & Rubber & 2,781 \\
4 & Coconut & 177 \\
5 & Paddy & 9,808 \\
6 & Corn & 1,733 \\
7 & Cassava & 271 \\
8 & Wood & 1,335 \\
9 & Cows and Buffalo & 535 \\
10 & Municipal Solid Waste & 2,066 \\
\hline \multicolumn{2}{l}{ Total Potential } \\
\hline
\end{tabular}

The system's techno-economic efficiency between coal and biomass is taking some aspects to be considered, such as the blending ratio of biomass and coal, loan ratio, electricity price and fuel price. The influence of biomass blending ratio on the economic indicators was nonlinear. So, the highest internal rate of return (IRR) for about $12-13 \%$ achieved with a $20-40 \%$ biomass ratio (Z. Wu \& OuYang, 2017). Moreover, techno-economic analysis for bio-DME (DME production using oil palm empty fruit bunches) in Riau, Indonesia, also economically feasible with a 10.08\% IRR generated. The data was generated from the simulation of 4.1 empty fruit bunches/DME and 1,090 tpd of DME produced with a selling price of IDR145,000/12-kg-LPG-equivalent (Parbowo et al., 2019). This enable to give the customer a cheaper alternative compared to LPG with a selling price of IDR150,000/12-kgLPG in 2021.

\subsection{Impacts}

\subsubsection{Environmental Impact}

DME is an environmentally friendly fuel with less harmful emissions than other fuels such as coal and LPG. The combustion of DME results in low $\mathrm{CO}, \mathrm{NO}_{\mathrm{x}}, \mathrm{SO}_{\mathrm{x}}, \mathrm{HC}$ (hydrocarbon) and $\mathrm{PM}$ (particulate matter). Increasing the DME's concentration in the DME-LPG blend decreases both the CO and $\mathrm{NO}_{\mathrm{x}}$ emission (Makmool \& Jugjai, 2013). CO emissions dropped from over 1,000 ppm to less than $200 \mathrm{ppm}$ at 5\% DME and zero $\mathrm{CO}$ emissions at 20\% DME. $\mathrm{NO}_{\mathrm{x}}$ reduced to its minimum at $15 \% \mathrm{DME}$. Furthermore, DME produces much lower solids, only $0.026 \%$, due to the high oxygen content and absence of direct C-C bonds (Makoś et al., 2019).

DME is a volatile organic compound that is non-carcinogenic and non-toxic. The compound itself is environmentally and global warming safe. DME atmospheric lifetime is 5.1 days with global warming potentials of 1.2 in a 20-year time horizon and 0.3 in a 100-year time horizon (Semelsberger, Borup, et al., 2006). Hence, DME is significantly less global warming potential than greenhouse gases. With its environmental benefits, DME can be used as a clean-efficient fuel. The implementation secures the environment aspect as one of the three pillars of sustainability.

Considering the environmental aspect of DME production, a life cycle assessment was done for a coal DME plant in South Korea (Kim et al., 2012). The assessment's scope started from coal mining, transportation and coal conversion into DME. For 1,000 tons of DME produced, 1,956 tons of coal were required. The $\mathrm{CO}_{2}$ emission factor was $1.46 \mathrm{~kg} \mathrm{CO}_{2} \mathrm{e}$ per $\mathrm{kg}$ DME. In comparison, LPG production emission factor is 5 times lower than DME at $0.3 \mathrm{~kg}$ CO2e per kg LPG (AEER, 2020; Shahrier et al., 2020) It is rational enough as DME production involve more chemical reaction and energy extensive. However, the DME emission can be reduced by utilizing biomass in co-processing (Lecksiwilai et al., 2016). Another advancement like $\mathrm{CO}_{2}$ capture also potentially to utilized for less carbon emitted. 


\subsection{Energy Security}

Based on General Planning of National (RUEN) 2017, DME is one of the Indonesian government concern to reduce LPG import. Primarily, the raw material resource is an essential aspect of producing DME. Crude oil, natural gas, coal and biomass are appropriate raw materials to produce DME. However, the decreasing oil reserve led to oil import and natural gas production barely enough for domestic demand, making coal and biomass the potential resources. Indonesia has a surplus of coal. Therefore, the allocation of coal for DME production will vary the energy distribution and suppress the LPG import.

There were two proposed scenarios on the DME implementation to substitute LPG to achieve energy security (Boedoyo, 2016). The scenarios were made considering the energy supply, available potency and DME application on related sectors. Scenario 1 was targeted to reduce $20 \%$ of LPG consumption by 2030, which was rated as the most feasible scenario. Scenario 2 with a $40 \%$ reduction target in 2030 rated as the most optimum scenario. Figure 6 shows LPG and DME's consumption in Million Barrel Oil Equivalent (MBOE) under each scenario and basic condition (without scenario). Moreover, Table 7 presents the requirement of natural gas, biomass and coal needed to run each scenario.

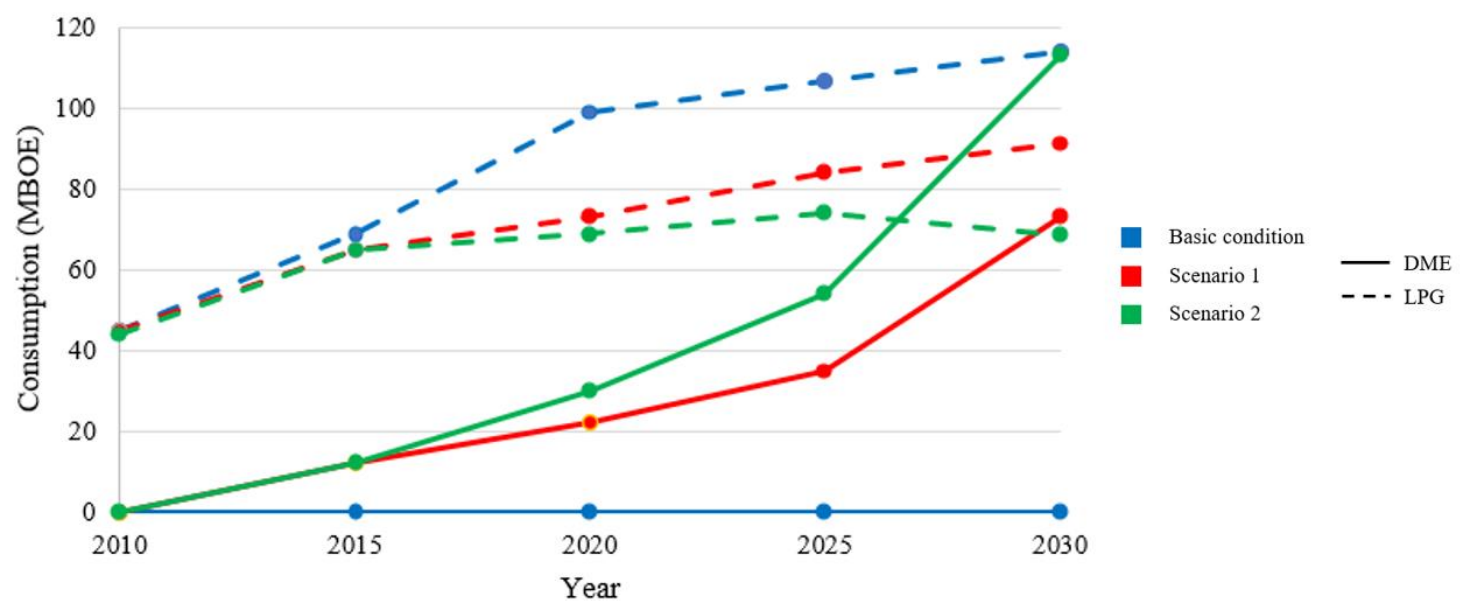

Figure 6. LPG and DME consumption on each scenario (Boedoyo, 2016).

Table 7. The requirement of natural gas, biomass and coal for each scenario (Boedoyo, 2016).

\begin{tabular}{|c|c|c|c|c|c|c|c|c|c|c|c|}
\hline \multirow{3}{*}{ Resources } & \multirow{3}{*}{ Scenario } & \multicolumn{10}{|c|}{ Year } \\
\hline & & \multicolumn{2}{|c|}{2010} & \multicolumn{2}{|c|}{2015} & \multicolumn{2}{|c|}{2020} & \multicolumn{2}{|c|}{2025} & \multicolumn{2}{|c|}{2030} \\
\hline & & $\%$ & MBOE & $\%$ & MBOE & $\%$ & MBOE & $\%$ & MBOE & $\%$ & MBOE \\
\hline \multirow{2}{*}{ Natural gas } & 1 & 0 & 0 & 40 & 4.62 & 20 & 4.34 & 0 & 0 & 0 & 0 \\
\hline & 2 & 0 & 0 & 40 & 4.62 & 20 & 6.06 & 0 & 0 & 0 & 0 \\
\hline \multirow{2}{*}{ Biomass } & 1 & 0 & 0 & 20 & 2.31 & 30 & 6.51 & 40 & 13.80 & 40 & 29.37 \\
\hline & 2 & 0 & 0 & 20 & 2.31 & 30 & 9.08 & 40 & 21.69 & 40 & 45.25 \\
\hline \multirow{2}{*}{ Coal } & 1 & 0 & 0 & 40 & 4.62 & 50 & 10.85 & 60 & 20.69 & 60 & 44.05 \\
\hline & 2 & 0 & 0 & 40 & 4.62 & 50 & 15.14 & 60 & 32.53 & 60 & 67.87 \\
\hline
\end{tabular}

In both scenarios, natural gas is only used until 2020 as its downtrend production. This is due to natural gas is also demanded by the industrial and power plant sector, make it limited to utilize. Therefore, by 2020 resources are supplied by coal and biomass. Biomass is utilized up to $40 \%$ of the total resources, after considered its availability and technology. Coal is projected to the dominant resource for DME production. This is aligned with the positive trend of Indonesia's coal production.

Achieving LPG energy security in Indonesia has to follow by the synergy of many sectors. In raw material resources, the coal export should be allocated for DME production. A more in-depth exploration of biomass is an essential task for the government to maximize the granted nature potential. Infrastructure, policy and technology are also crucial considerations for the fruitful DME. Although it 
seems out of reach to completely zero the LPG import, this study has confirmed that it is promising and feasible to cut the enormous import amount. Innovation like DME 100\% stove by LEMIGAS has to be considered to accelerate Indonesia to achieve LPG energy security.

\section{Conclusion and Suggestion}

Along with the weakened oil and gas production, an alternative fuel such as DME is needed to cover the massive LPG import amount. DME is proven suitable to substitute LPG. However, some property discrepancies between DME and LPG lead DME-LPG blend fuel to be the most feasible in this current state. By the optimum composition of 15-20\% DME, combustion efficiency was increased. The flame remained stable when tested in commercial LPG stoves, concluding that DME-LPG blend fuel is advantageous in households. In the raw material resources aspect, Indonesia, with a high abundance of coal reserves, can achieve its energy security by cutting LPG imports and producing its DME through coal gasification. The coal gasification process could be modified by co-processing with biomass, capturing the $\mathrm{CO}_{2}$ emission and utilizing the produced $\mathrm{CO}_{2}$ as the feedstock for the gasification process to reduce DME carbon footprint. The usage of coal and biomass to produce DME for LPG substitution can positively impact both economically and environmentally. It is projected with an IRR within 1013\%. Increasing the DME's concentration in the DME-LPG blend can decrease the CO for 80-100\% and $\mathrm{NO}_{\mathrm{x}}$ emission to its minimum. Moreover, a study has evaluated the potential of LPG to save Indonesia's energy security by cutting LPG imports up to $40 \%$.

More studies on feedstocks quality and supply need to be done before the direct implementation of DME. The quality of feedstocks could significantly affect the syngas produced, which will then be used as DME. Moreover, an integrated system regarding the DME synthesis plant and its distribution needs to be developed. More advances on the DME stove are also required to increase DME composition and burning efficiency before being commercially sold to consumers. In this study, the usage of DME to complement or substitute has been analyzed with result of slight modification on gas stove to comply with DME fuel. A sustainability study was also done regarding the usage of DME and its potential to be produced through co-gasification with biomass. To further reduce the environment impact of this process, carbon capture system can be implemented into the coal gasification system and the development of more effective catalyst is needed. Lastly, the government would have to convince households to shift their LPG usage into DME or DME-LPG blend fuel.

\section{References}

AEER. (2020). Coal Downstreaming in the Form of Dimethyl Ether (DME) Will Increase Greenhouse Gas Emissions.

Aguayo, A. T., Ereña, J., Mier, D., Arandes, J. M., Olazar, M., \& Bilbao, J. (2007). Kinetic Modeling of Dimethyl Ether Synthesis in a Single Step on a CuO-ZnO-Al 2 O $3 / \gamma-\mathrm{Al} 2$ O 3 Catalyst. Industrial \& Engineering Chemistry Research, 46(17), 5522-5530. https://doi.org/10.1021/ie070269s

Anggarani, R., Wibowo, C. S., \& Rulianto, D. (2014). Application of dimethyl ether as LPG substitution for household stove. Energy Procedia, 47, 227-234. https://doi.org/10.1016/j.egypro.2014.01.218

Armijo, J., \& Philibert, C. (2020). Flexible production of green hydrogen and ammonia from variable solar and wind energy: Case study of Chile and Argentina. International Journal of Hydrogen Energy, 45(3), 1541-1558. https://doi.org/10.1016/j.ijhydene.2019.11.028

Arya, P. K., Tupkari, S., K., S., Thakre, G. D., \& Shukla, B. M. (2016). DME blended LPG as a cooking fuel option for Indian household: A review. Renewable and Sustainable Energy Reviews, 53, 1591-1601. https://doi.org/10.1016/j.rser.2015.09.007

Azizi, Z., Rezaeimanesh, M., Tohidian, T., \& Rahimpour, M. R. (2014). Dimethyl ether: A review of technologies and production challenges. Chemical Engineering and Processing: Process Intensification, 82, 150-172. https://doi.org/10.1016/j.cep.2014.06.007

Basu, P. (2013). Biomass gasification, pyrolysis and torrefaction. Practical design and theory (2nd ed.). Elsevier Inc.

Batyrev, E., Vandenheuvel, J., Beckers, J., Jansen, W., \& Castricum, H. (2005). The effect of the reduction temperature on the structure of $\mathrm{Cu} / \mathrm{ZnO} / \mathrm{SiO} 2$ catalysts for methanol synthesis. Journal 
of Catalysis, 229(1), 136-143. https://doi.org/10.1016/j.jcat.2004.10.012

Boedoyo, M. S. (2016). Pemanfaatan Dimethyl Ether (DME) sebagai substitusi bahan bakar minyak dan LPG. Jurnal Teknologi Lingkungan, 11(2), 301. https://doi.org/10.29122/jtl.v11i2.1215

Brown, D. M., Bhatt, B. L., Hsiung, T. H., Lewnard, J. J., \& Waller, F. J. (1991). Novel technology for the synthesis of dimethyl ether from syngas. Catalysis Today, 8(3), 279-304. https://doi.org/10.1016/0920-5861(91)80055-E

Budya, H., \& Yasir Arofat, M. (2011). Providing cleaner energy access in Indonesia through the megaproject of kerosene conversion to LPG. Energy Policy, 39(12), 7575-7586. https://doi.org/10.1016/j.enpol.2011.02.061

Burnham, A. K. (2018). Van Krevelen Diagrams (pp. 1-5). https://doi.org/10.1007/978-3-319-023304 67-1

Centi, G., Quadrelli, E. A., \& Perathoner, S. (2013). Catalysis for CO2 conversion: a key technology for rapid introduction of renewable energy in the value chain of chemical industries. Energy \& Environmental Science, 6(6), 1711. https://doi.org/10.1039/c3ee00056g

Constantine, A. (2008). The potential of Dimethyl Ether(DME) asana alternative fuel for compressionignition engines: a review. Fuel, 87(7), 1014-1030.

DEN. (2018). Indonesia 's Energy Outlook. https://www.den.go.id/index.php/publikasi/download/70

Dirjen, M. (2018). Laporan Kinerja 2017.

ESDM. (2016). Investment Guidelines Bioenergy in Indonesia.

ESDM, K. (2020). Dimethyl Ether (DME) Sebagai Substitusi LPG di Indonesia.

Fahim, M. A., Alsahhaf, T. A., \& Elkilani, A. (2010). Acid gas processing and mercaptans removal. Fundamentals of Petroleum Refining (pp. 377-402). Elsevier. https://doi.org/10.1016/B978-0444-52785-1.00015-2

Fan, Y. J., \& Wu, S. F. (2016). A graphene-supported copper-based catalyst for the hydrogenation of carbon dioxide to form methanol. Journal of CO2 Utilization, 16, 150-156. https://doi.org/10.1016/j.jcou.2016.07.001

Fleisch, T. H., Basu, A., \& Sills, R. A. (2012). Introduction and advancement of a new clean global fuel: The status of DME developments in China and beyond. Journal of Natural Gas Science and Engineering, 9, 94-107. https://doi.org/10.1016/j.jngse.2012.05.012

Frusteri, F., Migliori, M., Cannilla, C., Frusteri, L., Catizzone, E., Aloise, A., Giordano, G., \& Bonura, G. (2017). Direct CO 2 -to-DME hydrogenation reaction: New evidences of a superior behaviour of FER-based hybrid systems to obtain high DME yield. Journal of CO2 Utilization, 18, 353-361. https://doi.org/10.1016/j.jcou.2017.01.030

Fujiwara, M., Ando, H., Tanaka, M., \& Souma, Y. (1994). Hydrogenation of carbon dioxide over $\mathrm{Cu}-$ $\mathrm{Zn}-\mathrm{Cr}$ oxide catalysts. Bulletin of the Chemical Society of Japan, 67(2), 546-550. https://doi.org/10.1246/bcsj.67.546

Gao, W., Wang, H., Wang, Y., Guo, W., \& Jia, M. (2013). Dimethyl ether synthesis from CO2 hydrogenation on La-modified CuO-ZnO-Al2O3/HZSM-5 bifunctional catalysts. Journal of Rare Earths, 31(5), 470-476. https://doi.org/10.1016/S1002-0721(12)60305-6

Ghasem, N. (2020). CO2 removal from natural gas. Advances in Carbon Capture (pp. 479-501). Elsevier. https://doi.org/10.1016/B978-0-12-819657-1.00021-9

Haryanto, A., Fernando, S., Murali, N., \& Adhikari, S. (2005). Current status of hydrogen production techniques by steam reforming of ethanol: A review. Energy \& Fuels, 19(5), 2098-2106. https://doi.org/10.1021/ef0500538

Howaniec, N., \& Smoliński, A. (2014). Effect of fuel blend composition on the efficiency of hydrogenrich gas production in co-gasification of coal and biomass. Fuel, 128, 442-450. https://doi.org/10.1016/j.fuel.2014.03.036

Huth, M., \& Heilos, A. (2013). Fuel flexibility in gas turbine systems: impact on burner design and performance. Modern Gas Turbine Systems (pp. 635-684). Elsevier. https://doi.org/10.1533/9780857096067.3.635

Inayat, A., Ghenai, C., Naqvi, M., Ammar, M., Ayoub, M., \& Hussin, M. N. B. (2017). Parametric study for production of dimethyl ether (DME) as a fuel from palm wastes. Energy Procedia, 105, 1242-1249. https://doi.org/10.1016/j.egypro.2017.03.431

Jeong, J. W., Ahn, C.-I., Lee, D. H., Um, S. H., \& Bae, J. W. (2013). Effects of Cu-ZnO content on reaction rate for direct synthesis of DME from syngas with bifunctional $\mathrm{Cu}-\mathrm{ZnO} / \gamma-\mathrm{Al} 2 \mathrm{O} 3$ 
catalyst. Catalysis Letters, 143(7), 666-672. https://doi.org/10.1007/s10562-013-1022-6

Johnson, E. (2009). Goodbye to carbon neutral: Getting biomass footprints right. Environmental Impact Assessment Review, 29(3), 165-168. https://doi.org/10.1016/j.eiar.2008.11.002

Kabir, K., \& Bhattacharya, S. (2011). Dimethyl ether production from gasification of victorian brown coal - process model and related preliminary experiments. CHEMECA 2011: Engineering a Better World: Sydney Hilton Hotel, NSW, Australia, 18-21 September 2011.

Kalinci, Y., Hepbasli, A., \& Dincer, I. (2009). Biomass-based hydrogen production: A review and analysis. International Journal of Hydrogen Energy, 34(21), 8799-8817. https://doi.org/10.1016/j.ijhydene.2009.08.078

Kim, S., Kim, J., \& Yoon, E. S. (2012). Evaluation of coal-based dimethyl ether production system using life cycle assessment in South Korea (pp. 1387-1391). https://doi.org/10.1016/B978-0-44459506-5.50108-5

Larson, E. D., \& Yang, H. (2004). Dimethyl ether (DME) from coal as a household cooking fuel in China. Energy for Sustainable Development, 8(3), 115-126. https://doi.org/10.1016/S09730826(08)60473-1

Lecksiwilai, N., Gheewala, S. H., Sagisaka, M., \& Yamaguchi, K. (2016). Net energy ratio and life cycle greenhouse gases (GHG) assessment of bio-dimethyl ether (DME) produced from various agricultural residues in Thailand. Journal of Cleaner Production, 134(Part B), 523-531. https://doi.org/10.1016/j.jclepro.2015.10.085

Li, K., Zhang, R., \& Bi, J. (2010). Experimental study on syngas production by co-gasification of coal and biomass in a fluidized bed. International Journal of Hydrogen Energy, 35(7), 2722-2726. https://doi.org/10.1016/j.ijhydene.2009.04.046

Liu, D., Yao, C., Zhang, J., Fang, D., \& Chen, D. (2011). Catalytic dehydration of methanol to dimethyl ether over modified $\gamma$-Al2O3 catalyst. Fuel, 90(5), 1738-1742. https://doi.org/10.1016/j.fuel.2011.01.038

Makmool, U., \& Jugjai, S. (2013). Thermal efficiency and pollutant emissions of domestic cooking burners using DME-LPG blends as fuel. The 4th TSME International Conference on Mechanical Engineering.

Makoś, P., Słupek, E., Sobczak, J., Zabrocki, D., Hupka, J., \& Rogala, A. (2019). Dimethyl ether (DME) as potential environmental friendly fuel. E3S Web of Conferences, 116, 00048. https://doi.org/10.1051/e3sconf/201911600048

Mamvura, T. A., \& Danha, G. (2020). Biomass torrefaction as an emerging technology to aid in energy production. Heliyon, 6(3), e03531. https://doi.org/10.1016/j.heliyon.2020.e03531

Marchionna, M., Patrini, R., Sanfilippo, D., \& Migliavacca, G. (2008). Fundamental investigations on di-methyl ether (DME) as LPG substitute or make-up for domestic uses. Fuel Processing Technology, 89(12), 1255-1261. https://doi.org/10.1016/j.fuproc.2008.07.013

Matsumoto, R., Ishihara, I., Ozawa, M., \& Imahori, K. (2004). Development of low-NOx emission DME (Dimethyl Ether) combustor. JSME International Journal Series B, 47(2), 214-220. https://doi.org/10.1299/jsmeb.47.214

MEMR. (2007). Kerosene to LPG conversion program 2007-2012. Ministry of Energy and Mineral Resources Republic of Indonesia.

MEMR. (2016a). Handbook of energy and economic statistics of Indonesia 2016. Ministry of Energy and Mineral Resources Republic of Indonesia.

MEMR. (2016b). Pencapaian program konversi s.d. tahun 2016. Ministry of Energy and Mineral Resources Republic of Indonesia.

Migliori, M., Aloise, A., Catizzone, E., \& Giordano, G. (2014). Kinetic analysis of methanol to dimethyl ether reaction over H-MFI catalyst. Industrial \& Engineering Chemistry Research, 53(38), 14885-14891. https://doi.org/10.1021/ie502775u

Miller, B. (2015). Greenhouse gas - carbon dioxide emissions reduction technologies. Fossil Fuel Emissions Control Technologies (pp. 367-438). Elsevier. https://doi.org/10.1016/B978-0-12801566-7.00008-7

Miller, B. G. (2011). Clean coal technologies for advanced power generation. Clean Coal Engineering Technology (pp. 251-300). Elsevier. https://doi.org/10.1016/B978-1-85617-710-8.00007-8

Naik, S. P., Ryu, T., Bui, V., Miller, J. D., Drinnan, N. B., \& Zmierczak, W. (2011). Synthesis of DME from $\mathrm{CO} 2 / \mathrm{H} 2$ gas mixture. Chemical Engineering Journal, 167(1), 362-368. 
https://doi.org/10.1016/j.cej.2010.12.087

Nieuwenhuis, P., \& Wells, P. (2003). Powertrain and fuel. The Automotive Industry and the Environment (pp. 73-86). Elsevier. https://doi.org/10.1016/B978-1-85573-713-6.50009-3

Ohno, Y. (2007). Slurry phase DME direct synthesis technology-100tons/day demonstration plant operation and scale up study. Stud Surf Sci Catal, 403-408.

Palo, D. R., Dagle, R. A., \& Holladay, J. D. (2007). Methanol steam reforming for hydrogen production. Chemical Reviews, 107(10), 3992-4021. https://doi.org/10.1021/cr050198b

Parbowo, H. S., Ardy, A., \& Susanto, H. (2019). Techno-economic analysis of dimethyl ether production using oil palm empty fruit bunches as feedstock - a case study for Riau. IOP Conference Series: Materials Science and Engineering, 543, 012060. https://doi.org/10.1088/1757-899X/543/1/012060

Prins, M. J., Ptasinski, K. J., \& Janssen, F. J. J. G. (2007). From coal to biomass gasification: Comparison of thermodynamic efficiency. Energy, 32(7), 1248-1259. https://doi.org/10.1016/j.energy.2006.07.017

Samei, E., Taghizadeh, M., \& Bahmani, M. (2012). Enhancement of stability and activity of $\mathrm{Cu} / \mathrm{ZnO} / \mathrm{Al} 2 \mathrm{O} 3$ catalysts by colloidal silica and metal oxides additives for methanol synthesis from a CO2-rich feed. Fuel Processing Technology, 96, 128-133. https://doi.org/10.1016/j.fuproc.2011.12.028

Sekretariat Jendral Dewan Energi Nasional. (2019). Laporan kajian penelaahan neraca energi nasional 2019. Kementerian Energi dan Sumber Daya Mineral, 1-79.

Semelsberger, T. A., Borup, R. L., \& Greene, H. L. (2006). Dimethyl ether (DME) as an alternative fuel. Journal of Power Sources, 156(2), 497-511. https://doi.org/10.1016/j.jpowsour.2005.05.082

Semelsberger, T. A., Ott, K. C., Borup, R. L., \& Greene, H. L. (2006). Generating hydrogen-rich fuelcell feeds from dimethyl ether (DME) using physical mixtures of a commercial $\mathrm{Cu} / \mathrm{Zn} / \mathrm{Al} 2 \mathrm{O} 3$ catalyst and several solid-acid catalysts. Applied Catalysis B: Environmental, 65(3-4), 291-300. https://doi.org/10.1016/j.apcatb.2006.02.015

Shahrier, F., Eva, I. J., Afrin, M., Alam, C. S., \& Rashid, A. R. M. H. (2020). Literature review on LCA of LPG as a transportation and cooking fuel. Proceedings of the International Conference on Industrial \& Mechanical Engineering and Operations Management.

Shim, H. M., Lee, S. J., Yoo, Y. D., Yun, Y. S., \& Kim, H. T. (2009). Simulation of DME synthesis from coal syngas by kinetics model. Korean Journal of Chemical Engineering, 26(3), 641-648. https://doi.org/10.1007/s11814-009-0107-9

Sugawa, S., Sayama, K., Okabe, K., \& Arakawa, H. (1995). Methanol synthesis from CO2 and H2 over silver catalyst. Energy Conversion and Management, 36(6-9), 665-668. https://doi.org/10.1016/0196-8904(95)00093-S

Takanabe, K. (2017). Photocatalytic water splitting: Quantitative approaches toward photocatalyst by design. ACS Catalysis, 7(11), 8006-8022. https://doi.org/10.1021/acscatal.7b02662

Tamagnini, P., Axelsson, R., Lindberg, P., Oxelfelt, F., Wünschiers, R., \& Lindblad, P. (2002). Hydrogenases and hydrogen metabolism of Cyanobacteria. Microbiology and Molecular Biology Reviews, 66(1), 1-20. https://doi.org/10.1128/MMBR.66.1.1-20.2002

Thoday, K., Benjamin, P., Gan, M., \& Puzzolo, E. (2018). The mega conversion program from kerosene to LPG in Indonesia: Lessons learned and recommendations for future clean cooking energy expansion. Energy for Sustainable Development, 46, 71-81. https://doi.org/10.1016/j.esd.2018.05.011

Vicente, J., Gayubo, A. G., Ereña, J., Aguayo, A. T., Olazar, M., \& Bilbao, J. (2013). Improving the DME steam reforming catalyst by alkaline treatment of the HZSM-5 zeolite. Applied Catalysis B: Environmental, 130-131, 73-83. https://doi.org/10.1016/j.apcatb.2012.10.019

von der Assen, N., Jung, J., \& Bardow, A. (2013). Life-cycle assessment of carbon dioxide capture and utilization: Avoiding the pitfalls. Energy \& Environmental Science, 6(9), 2721. https://doi.org/10.1039/c3ee41151f

Wambach, J., Baiker, A., \& Wokaun, A. (1999). CO2 hydrogenation over metal/zirconia catalysts. Physical Chemistry Chemical Physics, 1(22), 5071-5080. https://doi.org/10.1039/a904923a

Wu, N., Zhang, W., \& Huang, Z. (2008). Impact of dimethyl ether on engine seal materials. Front Energy Power Eng China, 2(3), 279-284.

Wu, Z., \& OuYang, D. (2017). Technical-economical analysis on co-gasification of coal and biomass 
based on the IGCC system with a two-staged gasifier. Energy Procedia, 142, 774-779. https://doi.org/10.1016/j.egypro.2017.12.125

Zha, F., Ding, J., Chang, Y., Ding, J., Wang, J., \& Ma, J. (2012). Cu-Zn-Al oxide cores packed by metal-doped amorphous silica-alumina membrane for catalyzing the hydrogenation of carbon dioxide to dimethyl ether. Industrial \& Engineering Chemistry Research, 51(1), 345-352. https://doi.org/10.1021/ie202090f

Zha, F., Tian, H., Yan, J., \& Chang, Y. (2013). Multi-walled carbon nanotubes as catalyst promoter for dimethyl ether synthesis from CO2 hydrogenation. Applied Surface Science, 285, 945-951. https://doi.org/10.1016/j.apsusc.2013.06.150

Zhang, Y., Li, D., Zhang, Y., Cao, Y., Zhang, S., Wang, K., Ding, F., \& Wu, J. (2014). V-modified $\mathrm{CuO}-\mathrm{ZnO}-\mathrm{ZrO} 2 / \mathrm{HZSM}-5$ catalyst for efficient direct synthesis of DME from $\mathrm{CO} 2$ hydrogenation. Catalysis Communications, 59, 52. https://doi.org/10.1016/j.catcom.2014.05.026 